\title{
KEISTIMEWAAN KUCING; KAJIAN TEMATIK HADIS
}

\author{
Andi Alda Khairul Ummah \\ Fakultas Ushuluddin Filsafat dan Politik UIN Alauddin Makassar \\ aldakhairulummah@gmail.com
}

\section{Abstrak}

Kucing merupakan salah satu hewan yang lucu dan menggemaskan, dia memiliki mata yang indah dan bulu yang lembut. Bahkan, kucing termasuk salah satu hewan yang di sebutkan dalam hadis Rasulullah saw. Tapi jika dilihat fenomena pada zaman sekarang ada orang yang begitu menyukai hewan tersebut dan ada juga yang sangat tidak manyukainya. Permasalahannya adalah sebagian orang yang tidak menyukai kucing dia tega menelantarkan dan menganiaya hewan tersebut. Sehingga, banyak kucing yang tinggal di jalanan atau pasar-pasar. Dalam hadis Rasulullah saw ada yang bercerita tentang orang yang masuk neraka akibat menganiaya hewan ini. Dalam mengkaji atau memahami hadis tersebut penulis menggunakan metode tahlili yang dimana menjelaskan kosa kata dan syarah hadis tersebut. Hasil dari pemahaman hadis yang diriwayatkan oleh Ibnu Umar adalah bahwa tidak boleh mengurung kucing dan tidak memberinya makan atau minum karena hal tersebut termasuk dalam menganiayanya. Karena mengurung kucing wanita itupun masuk neraka sebagaimana yang telah di sebutkan diatas bahwa itu merupakan bentuk penganiayaan terhadap kucing. Sehingga kucing tersebut mati. Tidak hanya kucing hewan lain pun kita tidak boleh menganiaya meraka. Maka dari hasil pemahaman hadis tersebut sudah semestinya kita sebagai manusia sangat penting dalam memelihara kucung dan tidak boleh menganiaya hewan termasuk kucing karena kucing merupakan hewan yang istimewa dan kesayangan Rasulullah saw.

Kata Kunci: Kucing, Istimewa, Hadis, Menganiaya.

\section{Pendahuluan.}

Kucing atau dalam bahasa lainnya di sebut Felis Silvestris, adalah sejenis karnivora (binatang pemakan daging) 
dari keluarga faliade yang sudah dijinakkan selama ribuan tahun. Kucing adalah hewan pemakan daging sejati. Kata kucing biasanya merujuk kepada "kucing" yang telah dijinakkan, tetapi bisa juga merujuk kepada kucing raksasa, seperti singa, harimau, macan dan sebagainya.

Kucing juga sudah di kenal sejak jaman kerajaankerajaan kuno sebagai binatang yang menemani sang raja atau sang ratu. Dalam islam, kucing sebagai hewan kesayangan Rasulullah saw. Hewan kesayangan merupakan hewan yang sangat menguntungkan untuk dikembangkan dengan berbagai tinjauan dan dapat memberikan sumbangan untuk kebahagiaan manusia. Salah satu hewan kesayangan yang perlu mendapat perhatian untuk di pelihara dan dikembangbiakkan adalah kucing. ${ }^{1}$

Kucing merupakan salah satu hewan peliharaan yang sangat lucu dan jinak. Meskipun demikian masih banyak orang yang beranggapan bahwa kucing merupakan hewan sihir dan bisa membawa bencana. Padahal itu merupakan anggapan yang salah. Banyak mitos mengenai hewan satu ini. Mulai dari ada yang mengatakan bahwa dia memiliki 9 nyawa dan dapat memberi karma bagi orang yang menyakitinya atau membunuhnya. Mitos yang mengatakan bahwa orang yang menyakiti atau membunuh kucing itu ada juga dalam hadis Rasulullah saw. Bahwa ada seorang wanita yang masuk neraka karena menganiaya kucing. Terlepas dari mitos mengenai kucing, islam pun sangat memuliakan hewan yang satu ini. Kucing merupakan hewan kesayangan Rasulullah saw, tak hanya kucing Rasulullah pun menyayangi hewan lain, bahkan

${ }^{1}$ Harini Nurcahya Mariandayani, "Keragaman Kucing Domestik felis domesticus berdasarkan Morfogenetik", Peternakan Sriwijaya 1, no. 1 (2012):h. 10. 
menurut Rasulullah memelihara hewan dapat menjadikan pahala baginya.

Memelihara kucing memiliki kesulitan tersendiri bagi kita. $^{2}$ Itulah sebabnya mengapa banyak orang yang menelantarkan kucing. Selain dari kesulitan dalam memelihara kucing sebagian besar juga orang takut dengan hewan tersebut dengan alasan masing-masing. Akan tetapi, jika kita memelihara kucing sebaiknya dan seharusnya kita memelihara hewan tersebut dengan baik, jangan sampai kita memelihara hewan terersebut dengan hanya mengurungnya dikandang kemudian tidak memberi makan. Karena hal itu termasuk dalam menganiayanya. Jika telah berkomitmen memelihara hewan ini harusnya memelihara dengan baik. Dan jika tidak memelihara dengan baik atau mengaiayanya hal ini bisa memasukkan kita kedalam neraka sebagaimana yang terdapat dalam hadis Rasulullah saw.

Tulisan ini akan menilite hadis berkaitan dengan kucing. Penelitian ini menggunakan metode tahlili yang dimana menjelaskan atau memaparkan makna kosa kata dan syarah hadis. Jika ayat-ayat al-Quran ingin dipahami, diperlukan tafsir. Demikian juga halnya dengan hadis di perlukan syarahnya. ${ }^{3}$ Metode tahlili merupakan metode analisa yang biasa digunakan dalam ilmu tafsir untuk menginterpretasi ayat-ayat al-Quran. Metode ini kemudian di adopsi oleh para pakar hadis dalam menginterpretasi hadis Nabi saw. Dari segi pengertian bahasa, tahlili berarti menjelaskan setiap bagian dari suatu jenis beserta fungsinya masing-masing. sedangkan defenisi terminologinya,

2 Anisa DKK, "Sistem Perawatan Kucing Berbasis Aturan”, Jurnal Sistem dan Teknologi 5, no. 4 (2017):h. 219.

${ }^{3}$ Andi Darussalam, "Aplikasi Metode Tahlili dalam Fiqhi Al-Hadis Telaah Kitab subul al-salam, hadis tentang sucinya air", Tafsere 2, no. 4 (2014):h. 175. 
metode tahlili adalah metode yang mengurai kosa kata dan lafaz. Dari defenisi tersebut bisa disimpulkan bahwa metode tahlili pada kita hadis adalah metode dengan menjelaskan kosa kata dan kalimat pada suatu hadis.

\section{Keistimewaan Kucing dalam Sejarah Islam}

Setiap orang memiliki rasa suka dalam dirinya termasuk salah satunya memelihara binatang, dengan memiliki binatang peliharaan biasanya bertujuan untuk memenuhi hasrat kebahagiaan bagi sebagian orang. Banyak yang memandang bahwa hewan peliharaan sebagai penawar strees ataupun kejenuhan selain itu juga hewan penjaga rumah seperti anjing, hewan ternak seperti ayam, kambing, sapi, dan lain sebagainya.

Kucing merupakan salah satu hewan peliharaan yang sangat popular di seluruh dunia termasuk di Indonesia. Dalam sejarah islam, kucing memiliki keistimewaan yang sangat luar biasa. Baginda Nabi Muhammad saw bahkan berpesan kepada para sahabatnya untuk menyanyangi kucing peliharaan, layaknya menyayangi keluarga sendiri. Salah satu kucing yang dimiliki oleh Nabi adalah Mueeza selalu mengeong ketika mendengar azan, dan seolah-olah suaranya terdengar seperti mengiikuti lantunan suara azan.

Pada abad ke 13, dalam dunia seni islam, rupa kucing dijadikan mata uang sebagai bentuk manifestasi penghargaan masyarakat islam. Sedangkan, dunia sastra, para penyair tak ragu untuk membuat syair bagi kucing peliharaannya yang telah berjasa itu. Penghormatan tokoh islam terhadap kucing pasca wafatnya Nabi Muhammad saw. Dalam buku yang berjudul Cats of Cairo dijelaskan pada dinasti mamluk, Baybars al Zahir, seorang sultan yang juga pahlawan garis depan dalam perang salib sengaja membangun taman-taman khusus bagi kucing dan 
menyediakan berbagai jenis makanan didalamnya. Tradisi ini telah menjadi adat istiadat di berbagai kota-kota besar Negara islam. Hingga saat ini, mulai dari damaskus, Istanbul hingga Kairo, masih bisa kita jumpai kucing-kucing yang berkeliaran di pojok-pojok masjid tua dengan berbagai macam makanan oleh penduduk setempat.

Kisah kucing yang memberi inspirasi bagi para sufi. Seorang sufi ternama bernama Ibnu Bashad yang hidup pada abad ke 10 hijriyah bercerita. Suatu saat ia dan sahabatsahabatnya sedang duduk santai melepas lelah diatap masjid kota Kairo sambil menikmati makan malam. Ketika seekor kucing melewatinya, Ibnu Bashad memberi sepotong daging kepada kucing itu, namun tak lama kemudian kucing itu kembali lagi, setelah memberinya potongan kedua, diam-diam Ibnu Bashad mengikuti kearah kucing itu pergi, hingga akhirnya ia sampai pada sebuah atap rumah yang kumuh, dan didapatinya si kucing tadi sedang menyodorkan sepotong daging yang diberikan Ibnu Bashad kepada kucing lain yang buta matanya. Peristiwa ini sangat menyentuh hatinya hingga ia menjadi sufi sampai ajal menjemputnya pada tahun 1067. Selain itu kaum sufi juga percaya bahwa dengkuran nafas kucing memiliki irama yang sama dengan dzikir kalimah Allah.

\section{Teks Hadis}

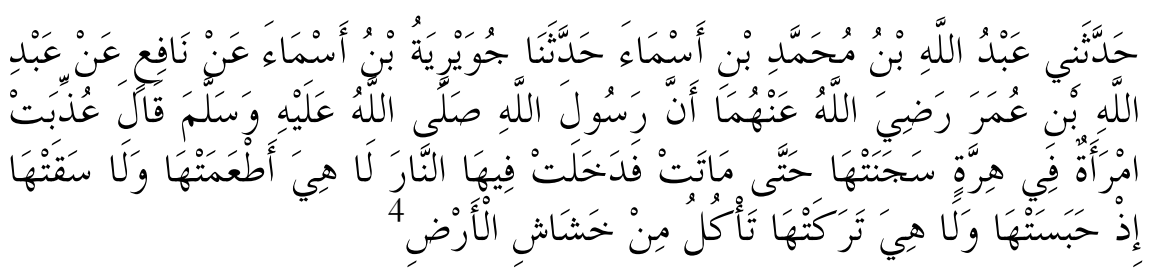

${ }^{4}$ Muhammad bin Isma>'il Abu> Abdullah al-Bukha>ri> al-Ju'fi>, alJ>a>mi' al-Musnad as-S\}ahi>h al-Mukhtas\}ar min Umuri Rasulullahi saw wa 
Artinya:

Telah bercerita kepadaku 'Abdullah bin Muhammad bin Asma' telah bercerita kepada kami Juwairiyah bin Asmai dari Nafi' dari 'Abdullah bin 'Umar radliallahu 'anhuma bahwa Rasulullah shallallahu 'alaihi wasallam bersabda: "Ada seorang wanita disiksa disebabkan seekor kucing yang dikurungnya hingga mati kelaparan lalu wanita itupun masuk neraka karena dia tidak memberinya makan dan minum ketika mengurungnya, dan tidak melepaskannya sehingga dia dapat menyantap serangga tanah".

Kosa kata:

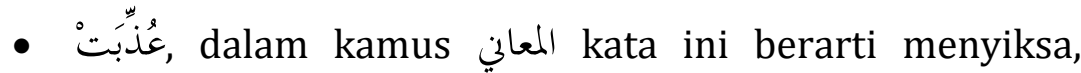
menyakitkan, menyerikan. kata menyiksa ini ditujukan kepada seorang wanita.

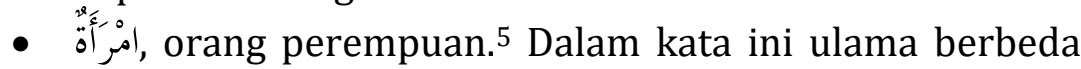
beda pendapat, ada yang mengatakan bahwa wanita yang di maksud disini adalah orang kafir, dan ada yang berpendapat bahwa wanita yang dimaksud adalah seorang muslimah

- هرَّة (kucing betina (kucing), kata ini ulama berpendapat bahwa kata ini berarti kucing betina, karena untuk kucing jantan adalah هر.

- فَدَخَحَلَتُ Masuk dalam hal ini di tujukan kepada wanita tadi.

- النَّارَ, api neraka, maksudnya disinilah tempat wanita itu dimasukkan sebab kucing tersebut.

Sunanihi wa ayya>mih, juz 4 (Cet. I; Damaskus: Dar Tauq an-Najah, 1422), h. 176.

${ }^{5}$ Ahmad Warson Munawwir, Al-Munawwir kamus Arab-Indonesia (Cet. II; Surabaya: Pustaka Progresif, 1997),h. 1322.

${ }^{6}$ Ahmad Warson Munawwir, Al-Munawwir kamus Arab-Indonesia, h. 392. 
- Ú, huruf ini di maknakan dengan arti tidak.

- $ن^{-1}$, memberi makan, maksudnya dia tidak memberi makan kepada kucing tersebut.

\section{Syarah Hadis}

Imam Bukhari menyebutkan dua hadis dalam bab ini yang masing-masing berasal dari Asma' binti Abu Bakar dan Ibnu Umar mengenai kisah wanita yang mengikat kucing hingga mati dan wanita itu masuk neraka. Kedua hadis ini disebutkan pada bab awal mula penciptaan. Adapun hadis Asma' telah disebutkan dengan lafaz yang lebih lengkap. Sedangkan hadis Ibnu Umar telah disebutkan oleh Ad-Daraquthni bahwa Ma'an bin Isa menyendiri dalam menyebutkannya di dalam kitab AlMuwaththa'. Dia berkata, "Hadis ini diriwayatkannya pula pada selain kitan Al-Muwaththa' oleh Ibnu Wahab, Al-Qa'nabi, Ibnu Abi Uwais dan Mutharrif." Lalu dia menyebutkan melalui jalur periwayatan mereka. Adapun Al-Ismaili telah meriwayatkan melalui jalur Ma'an dan Ibnu Wahab, sedangkan Abu Nu'aim melalui jalur Al-Qa'nabi.

Kesesuaian hadis tentang kucing dengan judul bab dapat dilihat dari sisi bahwa wanita itu di azab akibat tidak memberi minum kucing. Artinya, jika ia memberi minum, niscaya dia tidak diazab.Ibnu Al-Manayyar berkata, "hadis ini menerangkan tentang haramnya membunuh apa yang tidak diperintahkan untuk dibunuh dengan cara membuatnya kehausan, meskipun kucing dan tidak mendapatkan pahala karena memberi minum, akan tetapi menyelamatkannya telah cukup sebagai suatu kebaikan. $^{7}$

${ }^{7}$ Ibnu Hajar al-Asqalani, Fathul Bari Syarah Shahih al-Bukhari, terj. Amiruddin, Fathul Baari Penjelasan Kitab Shahih Bukhari, jilid 13 (Jakrata: Pustaka Azzam, 2010), h. 330. 
Dalam fathul bari' karya Ibnu Hajar al-Atsqalany beliau mengatakan bahwa yang dimaksud dengan wanita yang dimasukkan kedalam neraka ialah seorang wanita dari golongan Himyar, dalam riwayat lain dia disebutkan dari Bani Israil. Namun, tidak ada riwayat yang menyebutkan namanya. Hanya saja telah dikemukakan terdahulu bahwa dia berkulit hitam dan berasal dari suku Himyar dari kalangan Bani Israil. Disebutkan pula bahwa semua itu tidak bertentangan. ${ }^{8}$ Baihaqi menyebutkan dalam kitabnya bahwa wanita itu adalah seorang yahudi karena golongan Himyar kebanyakan beragama yahudi. Akan tetapi Nawawi memungkiri pernyataan tersebut. Sedangkan kucing yang dimaksud dalam hadis ini adalah seekor kucing betina. Karena kata هرة merupakan sebutan untuk seekor kucing betina dan kata هر merupakan sebutan untuk kucing jantan. Yang di maksud dengan خشاش adalah kutu tanah, serangga tanah, seekor tikus dan semisalnya. Nawawi berkata bahwa hadis ini diriwayatkan dengan huruf $\tau$ tanpa titik yang bermakna tumbuh-tumbuhan tanah. Ibnu Hajar mengatakan bahwa pendapat ini lemah dan keliru. Akan tetapi, jelasnya seorang wanita disiksa karena membunuh seekor kucing yang dikurungnya. Iyadh berkata wanita tersebut adalah seorang kafir dan disiksa dalam neraka. Atau karena dihisab karena barang siapa yang hisabanya jelek maka akan disiksa. Atau wanita tersebut sorang kafir dan disiksa karena kekafirnnya dan ditambah siksaannya karena perbuatannya tadi. Atau seorang itu wanita muslimah akan tetapi dimasukkan ke dalam neraka karena perbuatan maksiat tersebut. Pendapat ini memperkuat pendapat Baihaqi dalam kitabnya dan Abu Nu'aim dalam

8 Ibnu Hajar al-Asqalani, Fathul Bari Syarah Shahih al-Bukhari, terj. Amiruddin, Fathul Baari Penjelasan Kitab Shahih Bukhari, jilid 17 (Jakrata: Pustaka Azzam, 2010), h. 757. 
kitabnya.

Hadis ini mengatakan bahwa menyiksa seekor kucing adalah perbuatan dosa dan dapat menyebabkan seseorang masuk kedalam neraka. ${ }^{9}$ Hadis yang mulia ini menunjukkan kepada kita betapa islam sangat menjunjung tinggi kasih sayang. Tidak hanya kepada sesame manusia, bahkan kepada seekor binatang sekalipun. Akibat tidak menaruh kasih sayang kepada seekor kucing, perempuan tersebut harus merasakan perihnya siksa neraka. Imam Nawawi rahimahullah berkata, "hadis ini menunjukkan di haramkannya membunuh kucing dan diharamkan mengurungnya tanpa diberi makan dan minuman. Adapun dimasukkannya kedalam api neraka adalah karena perbuatannya itu. Zahir hadis menunjukkan bahwa perempuan tersebut beragama islam, meskipun demikian dia masuk neraka gara-gara menyiksa seekor kucing". Beliau juga menegaskan, "maksiat ini bukanlah dosa kecil, bahkan dia bisa berubah menjadi dosa besar apabila dilakukan secara terus-menerus..$^{10}$

Ini adalah kisah seorang wanita yang menurung kucing dan tidak memberinya makan dan minum hingga kucing itu mati kelaparan dan kehausan. Ini mennunjukkan kerasnya tabiat wanita itu betapa buruk akhlaknya serta tiadanya belas kasih di hatinya. Dia sengaja menyakiti. Jika di hatinya terdapat belas kasih, niscaya dia melepaskan kucing itu. Dan sepertinya dia mengurungnya sepanjang siang dan malam. Ia merasakan lapar dan haus denga suara memelas meminta bantuan dan

${ }^{9}$ M. Riad Hafidz Mubarok, "Makalah tentang hadis seorang wanita masuk neraka karena menyiksa seekor kucing kajian takhrij” makalah, (Universitas Islam Negeri Sunan Gunung Djati, Bandung, 15 februari 2014), h,-.

${ }^{10} \mathrm{Abu}$ Muslih Ari Wahyudi. 2013. Retrived Januari 10, 2020, from Website Muslim.or.id: https://muslim.or.id/11203-gara-gara-menyiksaseekor-kucing.html 
pertolongan. Suara dengan ciri tersendiri yang dikenal oleh orang-orang yang mengenal suara. Akan tetapi hati wanita ini telah membatu dan tidak terketuk oleh suara pilu kucing itu. ${ }^{11}$

Jika dilihat dari penjelasan atau syarah hadis yang dimana hadis ini juga terdapat dalam pembahasan keutamaan memberi air minum. Dalam bab ini terdapat beberapa hadis yang menjelaskan tentang memberi air minum kepada seekor anjing yang kehausan, maka Allah memberikan ampunan baginya. Jadi dapat dikatakan bahwa hadis ini merupakan anjuran berbuat baik, Karena apabila memberi minum pada seekor anjing diberi ampunan oleh Allah, maka pahala memberi minum seorang manusia adalah lebih besar. Hadis ini mengharuskan berbuat baik kepada hewan atau manusia yang memiliki kehormatan dan kebutuhan, keduanya pada tingkatan yang sama, maka yang lebih didahulukan manusia.

Jika hadis tentang memberi minum kepada anjing yang kehausan mendapat ampunan oleh Allah dan hadis yang mengurung kucing menjeruskan seorang wanita masuk kedalam neraka. Dapat disimpulkan bahwa berbuat baik kepada orang lain dan hewan akan mendapat ampunan dan jika menyiksa atau tidak berbuat baik kepada sesama dan hewan maka akan masuk kedalam neraka. Dalam hadis yang membahas tentang wanita masuk neraka karena mengurung kucing dan tidak memberinya makan itu tidak hanya berlaku pada kucing saja. Akan tetapi kepada hewan lainpun juga berlaku, apalagi kepada sesame manusia harus saling berbuat baik dan tidak saling menganiaya atau menzolimi.

${ }^{11}$ Admin. 2011. Retrived Januari 10, 2020, from Website Akhwat Muslimah.com:

http://www.akhwatmuslimah.com/2011/12/15/587/wanita-yang-masukneraka-karena-seekor-kucing/ 


\section{Keistimewaan dan Pahala Memelihara Kucing}

Kucing merupakan hewan yang dimuliakan dalam islam kucing merupaka hewan kesayangan Rasulullah. Lantas seperti apa keistimawaan kucing dalam islam? Allah sangat memuliakan semua makhluknya termasuk binatang. Seseorang bisa masuk neraka gara-gara tidak memberi makan hewan peliharaannya. Bahkan seekor kucing bisa membuat orang dijeburkan kedalam neraka. Islam menganjurkan semua umatnya untuk berbuat baik terhadap binatang peliharaan (kucing), karena didalamnya terdapat rida dan ampunan Allah. Rasulullah juga sangat menyayangi kucing dan memuliakan kucing, bahkan saat kucing kesayangannya tidur dijubahnya, Rsulullah memilih memotong lengan jubahnya agar tidak membangunkan kucing kesayangannya yang bernama Muezza. Dalam penjelasan lain juga mengatakan bahwa sisa air minum kucing sah untuk berwudhu, tidaklah najis karena beliau pernah berwudhu denga air bekas jilatan kucing.

Itulah keistimewaan kucing dalam islam, bahkan sebagai penghargaan dari tokoh islam pada abad 13, bentuk kucing diijadikan ukiran cincin untuk para khalifah. Dalam dunia sastra banyak penyair membuatkan syair untuk kicung yang dipeliharanya sebagai penghargaan atas jasa mereka yang menjaga buku dari gigitan serangga dan tikus. ${ }^{12}$

Pahala memelihara kucing:

1. Menjadi timbangan kebaikan saat kiamat

2. Melatih sikap empati

3. Mendapatkan rahmat dihari kiamat

4. Mendapat ampunan dan ridha Allah

12 Andi Supratna. 2018. Retrived januari 10, 2020, from website huffingtonpost.com: https://nulis.babe.news/baca/8f4830/keistimewaankucing-dalam-islam/ 
5. Merupakan sedekah

6. Dosa diampuni

7. Tidak memiliki banyak kuman

8. Kucing bukan merupakan hewan najis

9. Melindungi dari gigitan serangga serta tikus

10. Mempunyai irama serupa dzikir kalimah Allah

11. Kegiatan yang disukai Allah

12. Mendapat ganjaran yang baik dan surga

13. Air liur kucing adalah suci

14. Perhiasan rumah tangga

15. Disayang penghuni langit ${ }^{13}$

\section{Kesimpulan}

Kucing merupakan salah satu hewan peliharaan yang tinggal dirumah, hewan ini merupakann hewan kesayangan Rasulullah saw. Kucing telah dihargai di Timur sejak jaman dahulu, tradisi yang diadopsi oleh islam, meskipun sudah banyak yang berubah. Menurut hadis, Nabi Muhammad saw telah melarang penganiayaan dan pembunuhan terhadap kucing.

Banyak orang yang masih merasa takut untuk memelihara kucing karena bisa berdampak buruk untuk kesehatan. Akan tetapi, semua makhluk yang diciptakan Allah di muka bumi ini tentunya mempunyai kegunaan masing-masing seperti halnya dengan kucing. Meskipun ada sisi negatif dari hewan lucu ini seperti mencuri ikan di atas meja dan membuang kotoran, namun ternyata kucing juga memiliki keistimewaan dan bagi orang yang memelihara kucing juga akan memperoleh pahala. Misalnya, akan menjadi timbangan kebaikan di hari

13 Mareesa, “15 Pahala Memilihara Kucing Yang Istimewa”, agustus 25,2017. 
kiamat, mendapatkan rahmat di hari kiamat, mendapat ampunan dan ridha Allah.

Kemudian makna dari hadis yang bercerita tentang seorang wanita masuk ke dalam neraka karena mengurung kucing dan tidak memberinya makan dan minum hingga kucing tersebut mati karena lapar dan haus. Sebagai manusia kita harus saling berbuat baik terhadap sesama bahkan kepada hewanpun kita harus berbuat baik. Karena salah satu yang menjerumuskan manusia kedalam neraka adalah karena kerasnya hati seseorang yang tidak meiliki belas kasih terhadap sesama maupun kepada hewan.

Dalam hal ini tidak hanya kucing yang di larang untuk menganiayanya. Akan tetapi, seluruh makhluk ciptaan Allah swt yang ada di muka bumi ini. Baik itu manusia maupun hewan. Hadis yang diangkat oleh penulis kali ini merupakan hadis yang termasuk dalam shahih bukhari dan kerenanyak syarah di ambil dari syarah dari shahih bukhari itu sendiri ialah fathul baari'. 


\section{DAFTAR PUSTAKA}

Mariandayani, Harini Nurcahya, "Keragaman Kucing Domestik felis domesticus berdasarkan Morfogenetik", Peternakan Sriwijaya 1, no. 1 (2012).

Anisa DKK, "Sistem Perawatan Kucing Berbasis Aturan", Jurnal Sistem dan Teknologi 5, no. 4 (2017).

Darussalam, Andi, "Aplikasi Metode Tahlili dalam Fiqhi Al-Hadis

Telaah Kitab subul al-salam, hadis tentang sucinya air", Tafsere 2, no. 4 (2014).

al-Ju'fi>, Muhammad bin Isma>'il Abu> Abdullah al-Bukha>ri>, al-J>a>mi' al-Musnad as-S\}ahi>h al-Mukhtas\}ar min Umuri Rasulullahi saw wa Sunanihi wa ayya>mih, juz 4

Cet. I; Damaskus: Dar Tauq an-Najah, 1422.

Munawwir, Ahmad Warson Al-Munawwir, kamus Arab-Indonesia

Cet. II; Surabaya: Pustaka Progresif, 1997.

al-Asqalani, Ibnu Hajar, Fathul Bari Syarah Shahih al-Bukhari, terj. Amiruddin, Fathul Baari Penjelasan Kitab Shahih Bukhari, jilid 13 Jakrata: Pustaka Azzam, 2010.

al-Asqalani, Ibnu Hajar, Fathul Bari Syarah Shahih al-Bukhari, terj. Amiruddin, Fathul Baari Penjelasan Kitab Shahih Bukhari, jilid 17 Jakrata: Pustaka Azzam, 2010.

M. Riad Hafidz Mubarok, "Makalah tentang hadis seorang wanita masuk neraka karena menyiksa seekor kucing kajian takhrij" makalah, Universitas Islam Negeri Sunan Gunung Djati, Bandung, 15 februari 2014.

Wahyudi. Abu Muslih Ari, 2013. Retrived Januari 10, 2020, from Website Muslim.or.id: https://muslim.or.id/11203-garagara-menyiksa-seekor-kucing.html

Admin. 2011. Retrived Januari 10, 2020, from Website Akhwat Muslimah.com: 
102 | Keistimewaan Kucing; Kajian Tematik Hadis

http://www.akhwatmuslimah.com/2011/12/15/587/ wanita-yang-masuk-neraka-karena-seekor-kucing/

Supratna. Andi, 2018. Retrived januari 10, 2020, from website huffingtonpost.com:

https://nulis.babe.news/baca/8f4830/keistimewaankucing-dalam-islam/

Mareesa, "15 Pahala Memilihara Kucing Yang Istimewa", agustus $25,2017$. 